BIOCHEMISTRY OF PARASITIC PROTOZOA 


\title{
BIOCHEMISTRY OF PARASITIC PROTOZOA
}

\author{
W. E. GUTTERIDGE \\ Senior Lecturer in Biology, University of Kent \\ G. H. COOMBS
}

Lecturer in Zoology, University of Glasgow

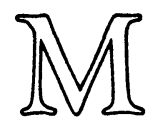


(C) W. E. Gutteridge and G. H. Coombs 1977

Softcover reprint of the hardcover 1st edition 1977

All rights reserved. No part of this publication may be reproduced or transmitted, in any form or by any means, without permission

\author{
First published 1977 by \\ THE MACMILLAN PRESS LTD \\ London and Basingstoke \\ Associated companies in Delhi Dublin \\ Hong Kong Johannesburg Lagos Melbourne \\ New York Singapore and Tokyo
}

ISBN 978-0-333-22779-4 ISBN 978-1-349-15809-6 (eBook)

DOI 10.1007/978-1-349-15809-6

This book is sold subject to the standard

conditions of the Net Book Agreement

The paperback edition of this book is sold subject to the condition that it shall not, by way of trade or otherwise, be lent, re-sold, hired out, or otherwise circulated without the publisher's prior consent in any form of binding or cover other than that in which it is published and without a similar condition including this condition being imposed on the subsequent purchaser 


\section{Contents}

Preface

1 Introduction to Parasitic Protozoa 1

1.1 What are protozoa?

1.2 Classification of the phylum Protozoa

1.3 Important genera of parasitic protozoa

1.4 Genus Trypanosoma

1.5 Genus Leishmania

1.6 Genus Trichomonas

1.7 Genus Entamoeba

1.8 Genus Eimeria

1.9 Genus Toxoplasma

1.10 Genus Plasmodium

1.11 Genus Babesia

1.12 Genus Theileria

1.13 Further reading

2 Control of Diseases caused by Parasitic Protozoa 18

$\begin{array}{ll}2.1 \text { Introduction } & 18\end{array}$

$\begin{array}{lll}2.2 & \text { Vaccination } & 18\end{array}$

$\begin{array}{ll}2.3 \text { Chemotherapy } & 20\end{array}$

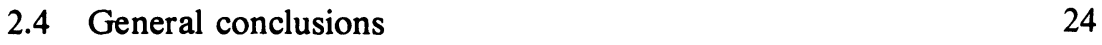

$\begin{array}{ll}2.5 & \text { Further reading } \\ & 25\end{array}$

3 Methodology 26

$\begin{array}{lll}3.1 & \text { Introduction } & 26\end{array}$

3.2 Laboratory maintenance 26

$\begin{array}{lll}3.3 & \text { Maintenance in vivo } & 27\end{array}$

3.4 Isolation from infected animals $\quad 29$

$\begin{array}{ll}3.5 & \text { Maintenance in vitro } \\ 3.6 & 29\end{array}$

3.6 Harvesting in vitro cultures $\quad 30$

$\begin{array}{lll}3.7 & \text { Washed cell suspensions } & 30\end{array}$

3.8 Cell breakage and subcellular fractionation 30 
3.9 General conclusions

3.10 Further reading

4 Catabolism and the Generation of Energy. I Stages Parasitic in Vertebrates

4.1 Introduction

4.2 The mammalian host $\quad 32$

4.3 Genus Trypanosoma 39

4.4 Genus Leishmania 44

4.5 Genus Trichomonas 45

4.6 Genus Entamoeba 48

4.7 Genus Eimeria $\quad 54$

4.8 Genus Plasmodium 54

4.9 Other genera 56

4.10 General conclusions $\quad 57$

4.11 Further reading 57

5 Catabolism and the Generation of Energy. II Stages Outside the Vertebrate Host 59

5.1 Introduction $\quad 59$

5.2 Genus Trypanosoma 59

5.3 Genus Leishmania $\quad 65$

5.4 Genus Entamoeba $\quad 66$

5.5 Genus Eimeria $\quad 66$

5.6 Genus Plasmodium 67

5.7 Other genera 67

$\begin{array}{lll}5.8 & \text { General conclusions } & 67\end{array}$

5.9 Further reading 68

6 Nucleic Acid Metabolism 69

$\begin{array}{lll}6.1 \text { Introduction } & 69\end{array}$

6.2 Purine metabolism 69

6.3 Pyrimidine metabolism 74

6.4 Deoxyribonucleotide metabolism 78

6.5 Nucleic acid synthesis $\quad 81$

6.6 DNA 81

6.7 Kinetoplast DNA $\quad 84$

6.8 RNA $\quad 86$

6.9 Nucleic acid catabolism $\quad 87$

$\begin{array}{ll}6.10 \text { General conclusions } & 87\end{array}$

6.11 Further reading $\quad 88$

7 Protein Metabolism $\quad 89$

$\begin{array}{lll}7.1 \text { Introduction } & 89\end{array}$ 
$\begin{array}{lll}7.2 & \text { Sources of amino acids } & 89\end{array}$

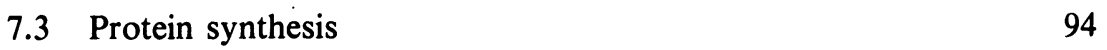

7.4 Catabolism and other metabolism of amino acids 96

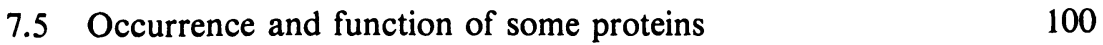

$\begin{array}{lll}7.6 & \text { Further reading } & 107\end{array}$

8 Lipid Metabolism 108

$\begin{array}{lll}8.1 \text { Introduction } & 108\end{array}$

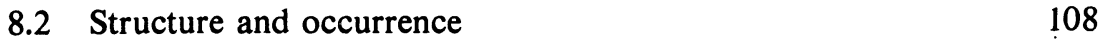

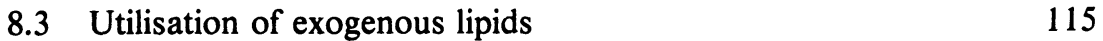

$\begin{array}{lll}8.4 & \text { Biosynthesis of lipids } & 116\end{array}$

$\begin{array}{lr}\text { 8.5 Catabolism of lipids } & 119\end{array}$

$\begin{array}{ll}\text { 8.6 General conclusions } & 120\end{array}$

$\begin{array}{ll}8.7 & \text { Further reading } \\ & 120\end{array}$

9 Biochemical Mechanisms of Drug Action 121

$\begin{array}{lll}9.1 & \text { Introduction } & 121\end{array}$

$\begin{array}{ll}\text { 9.2 Drugs interfering with energy metabolism } & 122\end{array}$

$\begin{array}{ll}\text { 9.3 Drugs interfering with membrane function } & 127\end{array}$

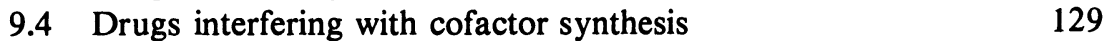

$\begin{array}{ll}\text { 9.5 Drugs interfering with nucleic acid synthesis } & 135\end{array}$

$\begin{array}{ll}\text { 9.6 Drugs interfering with protein synthesis } & 139\end{array}$

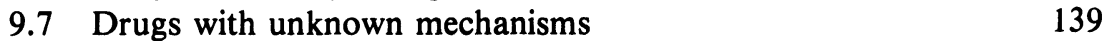

9.8 General conclusions about mechanisms of action 141

9.9 General conclusions about mechanisms of selective $\begin{array}{ll}\text { toxicity } & 141\end{array}$

$\begin{array}{ll}9.10 \text { Mechanisms of drug resistance } & 141\end{array}$

$\begin{array}{ll}9.11 \text { General conclusions } & 144\end{array}$

$\begin{array}{ll}9.12 \text { Further reading } & 145\end{array}$

10 Present Position and Future Prospects 146

Appendix A Isolation of Parasitic Protozoa from Infected Animals 148

$\begin{array}{lll}\text { A.1 Genus Trypanosoma (except T. cruzi) } & 148\end{array}$

$\begin{array}{llr}\text { A.2 Trypanosoma cruzi } & 149\end{array}$

A.3 Genus Leishmania 149

$\begin{array}{ll}\text { A.4 Genus Eimeria } & 149\end{array}$

$\begin{array}{lr}\text { A.5 Genus Toxoplasma } & 150\end{array}$

$\begin{array}{lr}\text { A.6 Genus Plasmodium } & 150\end{array}$

$\begin{array}{ll}\text { A.7 Further reading } & 151\end{array}$

Appendix B Culture of Parasitic Protozoa 152

B.1 Genus Trypanosoma (except $T$. cruzi) 152 
B.2 Trypanosoma cruzi

B.3 Genus Crithidia (except $C$. oncopelti)

B.4 Crithidia oncopelti

B.5 Genus Leishmania

B.6 Genus Trichomonas

B.7 Genus Entamoeba

B.8 Genera Eimeria, Toxoplasma and Theileria

B.9 Genus Plasmodium

B.10 General conclusions

B.11 Further reading

C.1 The presence of bipolar bodies

C.2 Initial conclusions

C.3 Doubts

C.4 The resolution of the problem

C.5 Further reading

Appendix D Biochemical Protozoology Literature

D.1 Literature searches

D.2 Current awareness

163

D.3 Advanced texts 


\section{Preface}

In recent years there have been several introductory texts dealing with different aspects of parasitic protozoa, but none has considered the subject biochemically. This book is an attempt to remedy the situation.

It is a résumé of our present (literature surveyed to December 1976) knowledge of the biochemistry of parasitic protozoa and the mode of action of the drugs useful in the treatment of the diseases they cause. The information is presented in a comparative manner; in each section, the protozoan metabolism is contrasted with that of the mammalian host and the differences between the two, which have been or might in future be exploited for chemotherapeutic purposes, are emphasised. Where the present situation is unclear because of the existence of conflicting information, only the conclusions from a critical appraisal are presented to avoid confusing the reader with unnecessary detail. The text makes it clear where this has been done. In addition to stating the known facts, an attempt is made also to point out the present deficiencies in our knowledge. To keep the length of the book within bounds and to reflect current research interests, only genera with species parasitic in man or domestic animals have been considered. To avoid confusing readers new to the field, no attempt has been made to credit the work described to individual scientists. We hope our colleagues will not be offended by this decision. Suggestions for further reading are included at the end of each chapter, and, where possible, these have been restricted to readily available books and review articles. Advice on how to follow the biochemical protozoology literature is given in appendix D.

The book is written in such a way that little prior knowledge of either biochemistry or protozoology is necessary and it is aimed at the final-year undergraduate, first-year postgraduate level. Thus it should be useful not only to intending protozoologists but also to students in the related fields of biochemistry, biology, medicine, microbiology, parasitology, veterinary medicine and zoology.

We are indebted to the following persons for the provision of photographs: Dr J. Alexander for figure 1.3c, Mr B. Cover for figures $1.3 \mathrm{a}, 1.3 \mathrm{~b}, 1.3 \mathrm{e}, 1.3 \mathrm{~g}$ and 1.3i; Dr V. S. Latter for figure 1.3f; Dr N. McHardy for figure 1.3j; Mr R. Newsam for figure 1.1; Professor G. Riou for figure 6.10; and Professor K. Vickerman for figure 7.5. We thank our colleagues in Canterbury and Glasgow for helpful discussions, Dr P. I. Trigg and Dr J. Williamson for reading parts of the manuscript and Mrs Sue Cover for her excellent typing of it.

W. E. Gutteridge

G. H. Coombs 